\title{
NEW HOST AND OCEAN RECORDS FOR DRIOCEPHALUS CEREBRINOXIUS (SPHYRIIDAE, SIPHONOSTOMATOIDA) AND A RECONSIDERATION OF PHYLOGENY WITHIN SPHYRIIDAE
}

\author{
George W. BENZ ${ }^{1 *}$, Kazuya NAGASAWA ${ }^{2}$, Atsuko YAMAGUCHI ${ }^{3}$, \\ Bailey C. MCMEANS ${ }^{4}$, Andrew MCELWAIN ${ }^{1}$ \\ ${ }^{1}$ Department of Biology, Middle Tennessee State University, Murfreesboro, TN 37132, USA \\ 2 Department of Bioresource Science, Graduate School of Biosphere Science, Hiroshima University, \\ Higashi-Hiroshima 739-8528, Japan \\ ${ }^{3}$ Faculty of Fisheries, Nagasaki University, Bunkyo, Nagasaki 852-8521, Japan \\ ${ }^{4}$ Formerly with Department of Biology, Middle Tennessee State University; presently with Fisheries Ecology \\ Research Group, Warnell School of Forest Resources, University of Georgia, Athens, GA 30606, USA
}

Benz G.W., Nagasawa K., Yamaguchi A., McMeans B.C., McElwain A. 2006. New host and ocean records for Driocephalus cerebrinoxius (Sphyriidae, Siphonostomatoida) and a reconsideration of phylogeny within Sphyriidae. Acta Ichthyol. Piscat. 36 (1): 1-9.

\begin{abstract}
Background. Driocephalus cerebrinoxius is an unusual representative of an unusual family of parasitic copepods (Sphyriidae, Siphonostomatoida, Copepoda). This report documents new host and ocean records for D. cerebrinoxius and considers the phylogenetic relationships amongst sphyriid (Sphyriidae) genera.

Materials and Methods. Copepods collected from trawl-caught fishes were studied using light microscopy and standard staining, manipulation, and measuring techniques. The phylogenetic analysis (parsimony outgroup analysis) was conducted using adult female morphological characteristics of sphyriid genera.

Results. Driocephalus cerebrinoxius is reported for the first time from the Pacific Ocean and from the star-spotted smooth hound, Mustelus manazo (Triakidae, Carcharhiniformes). The cladistic analysis of sphyriid taxa resulted in 12 shortest trees, each with a length of 16 and consistency index of 0.875 . Strict and majority rule consensus trees are presented.

Conclusions. Due to the paucity of morphological characters available for analysis, a robust phylogenetic hypothesis for taxa comprising Sphyriidae is best sought using molecular tools. Without a robust phylogeny it is premature to undertake associated analyses regarding historical ecology within Sphyriidae.
\end{abstract}

Keywords: parasitic copepods, Sphyriidae, Siphonostomatoida, mesoparasites, shark parasites, fish parasites, phylogeny

\section{INTRODUCTION}

Sphyriidae Wilson, 1919 (Siphonostomatoida, Copepoda) contains 9 genera and 35 species (Ho et al. 2003, Turner et al. 2003, Boxshall 2004) whose transformed adult females are highly modified mesoparasites (sensu Kabata 1979) of fishes. A member of Sphyriidae, Driocephalus cerebrinoxius (Diebakate, Raibaut et Kabata, 1997) was originally placed in Thamnocephalus (see Diebakate et al. 1997). However, subsequent discovery that Thamnocephalus Diebakate, Raibaut et Kabata, 1997 was a junior homonym of Thamnocephalus Packard, 1877, a genus comprised of fairy shrimp (Anostraca, Branchiopo- da), required the erection of Driocephalus Raibaut, 1999 to accommodate $T$. cerebrinoxius Diebakate, Raibaut et Kabata, 1997. Driocephalus cerebrinoxius is an unusual copepod, even amongst sphyriids (Sphyriidae), because it infects the nervous system of its host. Transformed adult females attach in and about the olfactory lobe with the posterior of the body trailing free within the lumen of the olfactory sac (Diebakate et al. 1997). We herein present the second report of $D$. cerebrinoxius based on collections representing new host and ocean records. We also present results of a phylogenetic analysis of relationships within Sphyriidae.

\footnotetext{
*Correspondence: Dr. George W. Benz, Department of Biology, P.O. Box 60, Middle Tennessee State University, Murfeesboro, TN 37132, USA, phone: (+615) 898-5021, fax: (+ 615) 898-5093, e-mail: gbenz@mtsu.edu
} 


\section{MATERIALS AND METHODS}

Seven star-spotted smooth hounds, Mustelus manazo Bleeker, 1854 (Triakidae, Carcharhiniformes); four females and three males, 532-995 mm total length, 479-3780 g body weight) were captured between July 1994 and January 1995 in Tokyo Bay, central Japan, using a trawl fishing at a depth of $20-50 \mathrm{~m}$. Sharks were transported on ice to the laboratory where copepods were collected from the olfactory sacs and fixed in $70 \%$ ethanol. For study, copepods were cleared and stained in a solution of lactic acid and lignin pink before being examined under a stereomicroscope. Illustrations were made with the aid of a drawing tube. Body features were measured by marking point to point lengths on paper using a drawing tube and then measuring these marks, using a stage micrometer. Body measurements are reported as $\bar{x} \pm s_{\bar{x}}$, general copepod terminology follows Kabata (1979), dorsal-ventral convention for copepods follows Diebakate et al. (1997), and host systematics follows Compagno (1999). Copepod voucher specimens have been deposited as follows: 3 specimens from 3 hosts deposited in the National Museum of Natural History, Smithsonian Institution, Washington, D.C. (USNM 1088537, 1088538, 1088539), and 4 specimens from 3 hosts deposited in the National Science $\mathrm{Mu}-$ seum (Tokyo, Japan) (NSMT-Cr 16826, 16827, 16828). The remaining 2 specimens are in the collection of the senior author.

A phylogenetic analysis of sphyriid genera was carried out based on adult female morphological characteristics. Character state polarity was determined using monotypic Ommatokoita Leigh-Sharpe, 1926 (Lernaeopodidae, Siphonostomatoida) as the outgroup. This decision repeated that of Dojiri and Deets (1988) regarding their phylogenetic analysis of Sphyriidae and was based on views that members of Sphyriidae and Lernaeopodidae share a common ancestor (Kabata 1979, Benz 1993) and O. elongata (Grant, 1827) is an underived lernaeopodid (Lernaeopodidae) (Kabata 1979, Dojiri and Deets 1988). A character state matrix was constructed for eight characters (Tables 1, 2) using information from the following sources: Kabata (1979) for Ommatokoita (outgroup); Diebakate et al. (1997) and information in this report for Driocephalus Raibaut, 1999; Hewitt (1964), Kabata (1979), Hogans and Dadswell (1985), Hogans (1986a), Ho and Kim (1989), and Boxshall (2000) for Lophoura Kölliker in Gegenbaur, Kölliker et Müller, 1853; Dojiri and Deets (1988) for Norkus Dojiri and Deets, 1988; Wilson (1908) for Opimia Wilson, 1908; Wilson (1919, 1932), Delamare-Deboutteville and Nuñes-Ruivo (1954), Kirtisinghe (1964), Lewis (1966), Kabata (1993), Castro Romero (2001), and Turner et al. (2003) for Paeon Wilson, 1919; Hewitt (1965), Kabata (1965), Hogans (1986b), and Ho et al. (2003) for Paeonocanthus Kabata, 1965; Wilson 1919 , Hogans 1986b, and Boxshall (2000) for Periplexis Wilson, 1919; Kabata (1979), Ho and Kim (1989), and Moran and Piasecki (1994) for Sphyrion Cuvier, 1830; and Kirtisinghe (1964), and Kabata (1979) for Tripaphylus Richiardi,
1880. Because the objective of the phylogenetic analysis was to evaluate relationships amongst sphyriid genera based on the commonly accepted view that Sphyriidae and its nine aforementioned genera are legitimate clades (Kabata 1979, Benz 1993, Boxshall 2004), an exhaustive search for basal synapomorphies for Sphyriidae and autapomorphies for sphyriid genera was not undertaken. Morphologic variation (see Tables 1,2 ) prompted us to consider Paeon spp. as being comprised of 2 groups. Paeon group A was comprised of P. ferox Wilson, 1919; P. elongatus Wilson, 1932; P. vaissierei Delamare-Deboutteville and Nuñes-Ruivo, 1954; P. lobatus Kirtisinghe, 1964, and P. asymboli Turner, Kyne, et Bennett, 2003. Paeon group B was comprised of P. versicolor Wilson, 1919; P. australis Kabata, 1993; and P. triakis Castro Romero, 2001. The most parsimonious cladogram was sought from all possible cladograms using the exhaustive search option of the software package PAUP* (Phylogenetic Analysis Using Parsimony [*and other methods]) version 4.0b-10 (Swofford 2002). In the phylogenetic analysis, characters were released from possible transformation series bias by using the unordered analysis option of PAUP. PAUP (Swofford 2002) was also used to construct a strict consensus tree and majority rule consensus tree (percent $=50$ ) from all of the aforementioned most parsimonious trees.

\section{RESULTS}

All seven examined sharks were infected with Driocephalus cerebrinoxius; five sharks infected with one copepod each, two sharks infected with two copepods each. The copepods match the description of $D$. cerebrinoxius well, although they are not fully intact, i.e., each lacks most or all of the cephalothorax. As noted by Diebakate et al. (1997), it is difficult to remove these mesoparasites from the host. In this case, it is likely that specimens were decapitated when they were removed from the olfactory sacs, such that the firmly embedded portions of the cephalothorax remained in situ. The body (Fig. 1A-C) is comprised of three general regions: cephalothorax, thoracic neck (neck), and genito-abdominal complex (trunk). The base of the cephalothorax is present on several specimens, as indicated by an enlarged area at the anterior of the neck (Fig. 1A-C). In addition, one specimen (see Fig. 1D) possesses remnants of the branching cephalothoracic dendrites that are unique to $D$. cerebrinoxius as well as two small hemispherical swellings that were interpreted by Diebakate et al. (1997) as possibly being reduced appendages (first or second antennae). The neck of all specimens is cylindrical and thin, $0.44 \pm 0.02 \mathrm{~mm}$ wide $(n=9), 6.07$ $\pm 0.82 \mathrm{~mm}$ long $(n=5)$. Trunk (Fig. 1A-C) $3.72 \pm 0.24$ mm wide $(n=7)$ at midpoint, $5.77 \pm 0.43 \mathrm{~mm}$ long $(n=7)$ not including posterior processes, roughly orbicular, slightly dorsoventrally depressed, dorsal aspect with convex contour (Fig. 1A, B), ventral surface with shallow concave contour (Fig. 1C), anterolateral margins rounded, lateral and some dorsal margins appear swollen in several places, posterior margins with two pairs of lateral lobes, ventral 
Table 1

Descriptions of eight characters and character states used in phylogenetic analysis of Sphyriidae Wilson, 1919: plesiomorphic state (code 0) defined first, followed by apomorphic states (codes in parentheses as Arabic numerals); see Fig. 2A for placement of parsimony informative synapomorphies on strict consensus tree

\begin{tabular}{|c|c|c|}
\hline Character & Character & Character state \\
\hline 1 & General habitus & $\begin{array}{l}\text { a. body without long neck }(0) \\
\text { b. body with long neck (1; a parsimony } \\
\text { uninformative basal synapomorphy) }\end{array}$ \\
\hline 2 & Posterior processes & $\begin{array}{l}\text { a. absent (0) } \\
\text { b. present as single unconstricted cylinders (1) } \\
\text { c. present as single constricted cylinders (2) } \\
\text { d. present as branched processes (3) }\end{array}$ \\
\hline 3 & Trunk & $\begin{array}{l}\text { a. appreciably longer than wide, } \\
\text { merges gradually with neck }(0) \\
\text { b. broad, roughly orbicular or rhomboid } \\
\text { in dorsal view, well delimited from neck (1) }\end{array}$ \\
\hline 4 & Neck & $\begin{array}{l}\text { a. cylindrical, not inflated, projections absent (0) } \\
\text { b. cylindrical, inflated anteriorly, projections absent (1) } \\
\text { c. with multiple projections in single transverse } \\
\text { plane (2) } \\
\text { d. with multiple projections in multple transverse } \\
\text { planes along length (3) }\end{array}$ \\
\hline 5 & Cephalothorax & $\begin{array}{l}\text { a. compact, lacking protuberances except for slight } \\
\text { anterior antennal bulge on cephalon }(0) \\
\text { b. compact or not, with truly unbranched, blunt or } \\
\text { pointed bilaterally symmetrical swellings or } \\
\text { outgrowths (1) } \\
\text { c. with branched outgrowths stemming from } 2 \text { main } \\
\text { bilateral branches (2) } \\
\text { d. with profuse and bush-like outgrowths (3) }\end{array}$ \\
\hline 6 & First antenna & $\begin{array}{l}\text { a. segmented, uniramous, resembling that in } \\
\text { Lernaepodidae (0) } \\
\text { b. vestigial papilla or absent (1) }\end{array}$ \\
\hline 7 & Second antenna & $\begin{array}{l}\text { a. biramous, resembling that in Lernaeopodidae }(0) \\
\text { b. vestigial papilla or absent (1) }\end{array}$ \\
\hline 8 & Maxilliped & $\begin{array}{l}\text { a. subchelate }(0) \\
\text { b. vestigial papilla or absent (1) }\end{array}$ \\
\hline
\end{tabular}

pair slightly anterior to dorsal pair (Fig. 1B, E), ventral lobes simple subspherical swellings, dorsal lobes each comprised of two confluent swellings that appear to protect basal portions of egg sacs (Fig. 1E). Posterior processes allantoid (Fig. 1C), $1.68 \pm 0.28 \mathrm{~mm}$ wide $(n=10)$ at midpoint, $2.23 \pm 0.09 \mathrm{~mm}$ long $(n=10)$, much shorter than main portion of trunk (Fig. 1B, C), attached just ventral to perianal swelling (Fig. 1E). Abdomen a small bilobed perianal swelling located ventral to openings of oviducts (Fig. 1E). Egg sacs allantoid, multiseriate (Fig. 1A-C), $1.47 \pm 0.05 \mathrm{~mm}$ wide $(n=11)$ at midpoint, $4.43 \pm 0.25 \mathrm{~mm}$ long $(n=11)$. No males observed or collected.

Twelve most parsimonious trees (tree length $=16$ steps, consistency index $=0.875$ ) resulted from the cladis- tic analysis of Sphyriidae. One of the 8 morphological characters (Character 1; see Tables 1,2) used in the analysis was parsimony uninformative, i.e., a basal synapomorphy for Sphyriidae. One strict consensus tree (Fig. 2A) and one $50 \%$ majority rule consensus tree (Fig. 2B) resulted from a consensus of the aforementioned 12 shortest trees. None of the aforementioned trees was fully resolved. Nevertheless, Periplexis and Paeonocanthus were depicted as sister taxa on all trees (e.g., see Fig. 2A, B). Lophoura and Sphyrion were depicted as sister taxa on $50 \%$ of the most parsimonious trees, while Lophoura and Driocephalus were depicted as sister taxa on the other $50 \%$ of all most parsimonious trees. Paeon group A and Paeon group B were depicted as independent taxa on all 

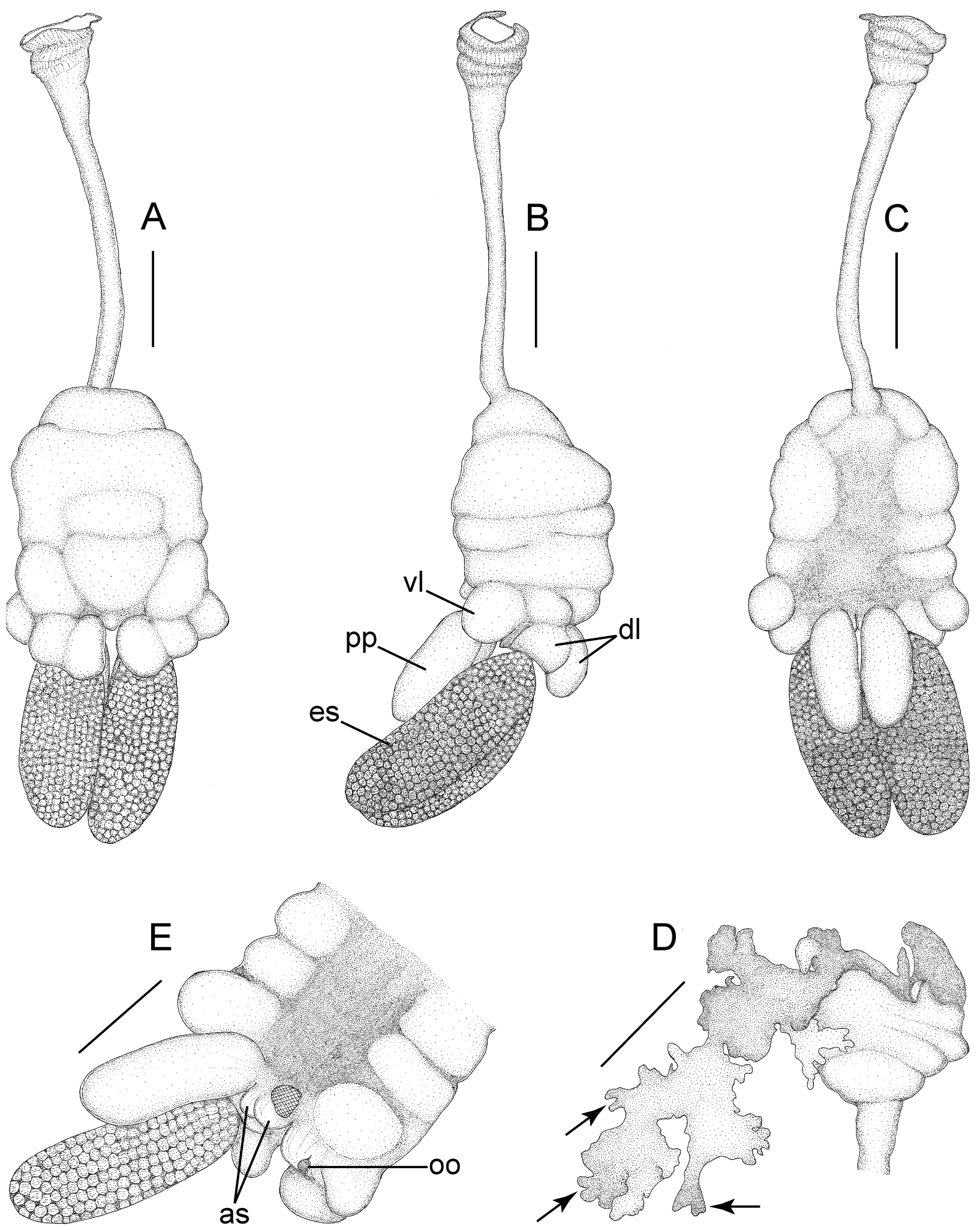

Fig. 1. Driocephalus cerebrinoxius; ovigerous females, partial specimens lacking most of cephalothorax; scale bars $=2 \mathrm{~mm}$; (A) general habitus, dorsal view; (B) general habitus, lateral view; vl, ventral trunk lobe; dl, dorsal trunk lobe; pp, posterior processes; es, egg sac; (C) general habitus, ventral view; (D) cephalothorax, ruptured, remnants of cephalothoracic dendrites evident (arrows); (E) posterior of body, oblique ventral view; one posterior process removed from region denoted by cross-hatching, left egg sac removed to expose oviduct opening (oo); as, bilobed perianal swelling 
Ovigerous female character states for eight characters used in the phylogenetic analysis of Sphyriidae Wilson, 1919; codes $0,1,2$, and 3 within data matrix identify particular character states for each character as defined in Table 1; code 0 indicates a plesiomorphy rather than an absence, code $\mathrm{M}$ indicates missing (unknown) or ambiguous data;

Ommatokoita Leigh-Sharpe, 1926 served as the outgroup; number of species accumulated from information in Ho et al. (2003), Turner et al. (2003), and Boxshall (2004); see text for details regarding information sources supporting character state designations not explained by footnotes

\begin{tabular}{lccccccccc}
\hline & \multicolumn{7}{c}{ Character } \\
\cline { 3 - 9 } Taxon & No. spp. & 1 & 2 & 3 & 4 & 5 & 6 & 7 & 8 \\
\hline Ommatokoita & 1 & 0 & 0 & 0 & 0 & 0 & 0 & 0 & 0 \\
Driocephalus & 1 & 1 & 1 & 1 & 0 & 3 & 1 & 1 & 1 \\
Lophoura & 16 & 1 & 3 & 1 & 2 & 1 & 1 & 1 & 1 \\
Norkus & 1 & 1 & 1 & 1 & 1 & 2 & 0 & 0 & 0 \\
Opimia & 1 & 1 & 1 & 0 & 0 & 0 & $\mathrm{M}^{*}$ & $0^{\dagger}$ & 0 \\
Paeon group A & 5 & 1 & 1 & 0 & 0 & 1 & $\mathrm{M}^{\dagger}$ & 0 & 0 \\
Paeon group B & 3 & 1 & 1 & 1 & 0 & 1 & $\mathrm{M}$ & $\mathrm{M}$ & 0 \\
Paeonocanthus & 2 & 1 & 1 & $\mathrm{M}^{* *}$ & 3 & 1 & 1 & 1 & 0 \\
Periplexis & 1 & 1 & 2 & 1 & 3 & 0 & 1 & 1 & $\mathrm{M}$ \\
Sphyrion & 3 & 1 & 3 & 1 & 0 & 1 & 1 & 1 & 0 \\
Tripaphylus & 2 & 1 & 1 & 0 & 0 & 1 & 0 & 0 & 0 \\
\hline
\end{tabular}

*The description of this appendage by Wilson (1919: p. 460) as, "one-jointed papilla on either side of mouth tube, a mere stump, apparently immovable," stymies character state designation.

${ }^{\dagger}$ Wilson (1908; p. 460) described the second antenna of Opimia exilis Wilson, 1908 as uniramous. However, his small illustration (see Wilson 1908; Figure 104) depicted this structure as likely being biramous and akin to those possessed by lernaeopodids (Lernaeopodidae).

$\$$ Paeon group A is comprised of P. ferox Wilson, 1919; P. elongatus Wilson, 1932; P. vaissierei Delamare-Deboutteville and NuñesRuivo, 1954; P. lobatus Kirtisinghe, 1964, and P. asymboli Turner, Kyne, et Bennett, 2003.

$\S$ Paeon group B is comprised of P. versicolor Wilson, 1919; P. australis Kabata, 1993; and P. triakis Castro Romero, 2001.

${ }^{* *}$ Character state coded as ambiguous because together, general habitus illustrations in Hewitt (1965), Kabata (1965), Hogans (1986b), and Ho et al. (2003) expose intrageneric and intraspecific variation that prevents certain allocation as code 0 or 1.

trees (e.g., see Fig. 2A, B). Most non-terminal branches on all trees were supported by 1 synapomorphy and no branch was supported by more than 2 apomorphies.

\section{DISCUSSION}

We assigned our specimens to Driocephalus cerebrinoxius based on three lines of evidence. First, amongst sphyriids, D. cerebrinoxius has a uniquely shaped trunk and cephalothorax (Diebakate et al. 1997). Second, D. cerebrinoxius is the only sphyriid that infects the olfactory organ of elasmobranchs and only copepod known to infect the olfactory lobe (Diebakate et al. 1997). Third, it is not unusual for sphyriid species to infect multiple species or for them to possess wide geographic distributions, e.g., see Ho (1992) regarding the distribution of Sphyrion lumpi (Krøyer, 1845). Based on this species assignment, this report is a new host record (M. manazo) and new ocean record (western Pacific) for D. cerebrinoxius. However, it should be noted that Yamaguchi et al. (2003) reported these specimens, as well as others collected from the same host species captured off Maizuru, Japan, in the Sea of Japan, as an unidentified genus and species of
Sphyriidae. Yamaguchi et al. (2003) reported the prevalence of this sphyriid infecting M. manazo as 3.3 and 1.0 in Tokyo Bay (213 hosts examined) and off Maizuru (93 hosts examined) respectively. In that report (loc. cit.) the infection site of the copepods was erroneously switched. In fact, D. cerebrinoxius (reported as Sphyriidae gen. sp.) was collected from the nostril (i.e., olfactory sac) while Perissopus oblongatus was collected from the fin. The authority and date for P. oblongatus was not provided by Yamaguchi et al. (2003) but it was likely (Wilson, 1908). Perissopus oblongatus (Wilson, 1908) is considered a junior synonym of Achtheinus oblongus Wilson, 1908 as proposed by Ho (1975) and recently endorsed by Benz et al. (2003). Diebakate et al. (1997) reported D. cerebrinoxius infecting the barbeled hound shark, Leptocharias smithii (Müller et Henle, 1839) (Leptochariidae), off Senegal (eastern Atlantic), the sandbar shark, Carcharhinus plumbeus (Nardo, 1827) (Carcharhinidae), in the Gulf of Gabès (Mediterranean Sea), and the bigeye hound shark, Iago omanensis (Norman, 1939) (Triakidae), in the Red Sea. The relatively wide distributions of some of the aforementioned sharks (e.g., see C. plumbeus in Compagno et 

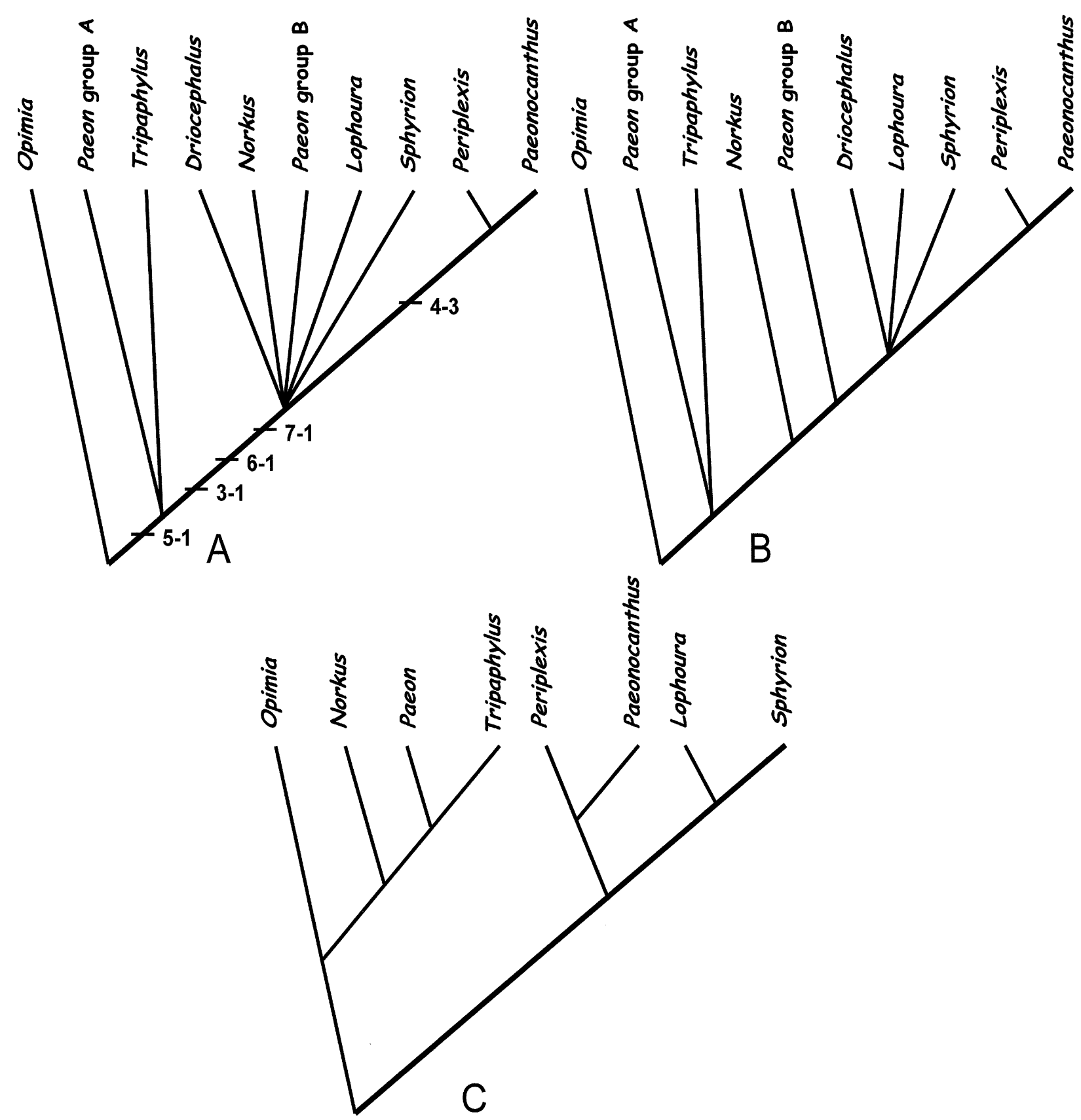

Fig. 2. Cladograms for sphyriid (Sphyriidae) taxa; (A) strict consensus cladogram (Rohlf's consistency index $=0.417$ ) resulting from consideration of all (i.e., 12) shortest cladograms (all 16 steps, consistency indices $=0.875$ ) of the present study; parsimony informative synapomorphies mapped along tree trunk (first numeral $=$ character and second numeral $=$ state as described and allocated in Tables 1, 2); (B) majority rule $(50 \%)$ cladogram (Rohlf's consistency index $=0.667$ ) resulting from consideration of all 12 shortest cladograms of the present study; (C) cladogram of sphyriid genera reported by Dojiri and Deets (1988); note that monotypic Driocephalus was erected (with the discovery of $D$. cerebrinoxius) after this cladogram was originally published

al. 2005) suggest that $D$. cerebrinoxius may infect these species elsewhere in temperate or tropical coastal waters. Furthermore, given that $D$. cerebrinoxius has been reported infecting representatives of three families of carcharhiniforms (Carcharhiniformes), it is likely that future host records may include additional species of these "ground sharks."

Diebakate et al. (1997) did not propose an explicit hypothesis regarding the phylogenetic relationship of Drio- cephalus to other sphyriid genera. Therefore, it was our intension to use our new observations and the literature to extend the phylogenetic analysis of Sphyriidae published by Dojiri and Deets (1988) to include Driocephalus. However, our review of the characters and character states used by Dojiri and Deets (1988) sometimes placed us at odds and ultimately prompted us to produce a new analysis. Given the relatively widespread adoption of the phylogenetic hypothesis for Sphyriidae presented by Dojiri 
and Deets (1988) and especially the interest shown in its associated hypotheses regarding host-parasite coevolution and parasite historical ecology (e.g., see Ho 1992, Paterson and Poulin 1999, Roberts and Janovy 2000, Boxshall 2000, 2004), we consider it important to herein list our concerns regarding some of the characters used in that analysis.

Character A (body condition): Dojiri and Deets (1988) considered sphyriids to exhibit a rotated body condition, i.e., torsion. While torsion has been mentioned as a characteristic of a few sphyriids (see Kabata 1979), Wilson (1919), Kabata (1979), Benz (1993), and Boxshall (2004) did not mention torsion as a synapomorphy for Sphyriidae. Wilson (1919) provided the best description of torsion within Sphyriidae, mentioning that this body twisting stems from the parasite growing while changing its path through the host to affect contact with a particular host structure. Thus the existence of torsion in sphyriids is dictated by environmental factors and may vary (Wilson 1919).

Character B (egg sac length): Dojiri and Deets (1988) considered the egg sacs of sphyriids to be elongate relative to those of $O$. elongata. However, we consider the egg sac length of $O$. elongata relative to either total body length or trunk length to be within the length range or longer than the eggs sacs of sphyriids. For example, relative to trunk length, the egg sacs of $P$. vaissierei (see figure 15 in Delamare-Deboutteville and Nuñes-Ruivo 1954) are similar to those of $O$. elongata (see figure 34.17 in Roberts and Janovy 2000), while relative to total body length, the egg sacs of $O$. elongata are longer than those of $P$. vaissierei (loc. cits.).

Characters D-J (posterior processes): Dojiri and Deets (1988) combined information regarding length (short, long) and shape (tubercular, cylindrical, transversely constricted, branching, grape-like) to create characters D-J. However, we found no evidence to support that amalgamation. In addition, Dojiri and Deets (1988) considered O. elongata to possess posterior processes (characters D-J) when it does not (see Kabata 1979, Benz et al. 1998). Regarding length of the posterior processes, Dojiri and Deets (1988) considered the posterior processes of some sphyriids to be short (i.e., Paeonocanthus, Periplexis) or long (i.e., Norkus, Opimia, Paeon, Tripaphylus). Using the literature, we calculated a range for the length of the posterior processes as a percentage of total body length from $7.5 \%$ for one Paeonocanthus specimen to about $34 \%$ in Paeon triakis (Driocephalus ca. $17.5 \%$ according to Diebakate et al. 1997; Lophoura variable but can be less than $10 \%$ according to Kabata 1979 , Ho and Kim 1989 , and Boxshall 2000; Norkus ca. 36\% according to Dojiri and Deets 1988; Opimia ca. $22.8 \%$ according to Wilson 1908; Paeon ranging from ca. $17 \%$ to $34 \%$, see below; $\mathrm{Pa}$ eonocanthus ranging from ca. $7.5 \%$ to $12.5 \%$ according to Hewitt 1965, Hogans 1986b, and Ho et al. 2003; Periplexis ca. 13\% according to Wilson 1919; Sphyrion ca. $15 \%-17 \%$ according to Kabata 1979; and Ho and Kim 1989; Tripaphylus ca. $29.6 \%$ according to Kirtisinghe
1964). We noted no trend regarding genus-level patterns of these data and in some instances wide variation existed amongst mature congeners and even species. For example, amongst Paeon spp. this character ranged from about $17 \%$ to $34 \%$ (P. asymboli ca. $19 \%-21.3 \%$ according to Turner et al. 2003; P. australis ca. 22.3\%-27.6\% according to Kabata 1993 and Turner et al. 2003; P. elongatus ca. $20.2 \%$ according to Wilson 1932; P. ferox ca. $32.7 \%$ according to Wilson 1919 ; P. lobatus ca. 31\%-34\% according to Kirtisinghe 1964, and Lewis 1966; P. triakis ca. $21 \%$ according to Castro Romero 2001; P. vaissierei ca. $31.6 \%$ according to Delamare-Deboutteville and NuñesRuivo 1954; P. versicolor ca. $17 \%$ according to Wilson 1919).

Characters $\mathrm{K}$ and L (genital complex): we did not agree with allocation of the genital complex character states ovoid, gradually expanding, and discoid in the analysis of Dojiri and Deets (1988). The trunk (i.e., genital complex in Dojiri and Deets 1988), of O. elongata appears (see Kabata 1979, Benz et al. 1998) more like the gradually expanding condition noted by Dojiri and Deets (1988) for taxa such as Opimia, Paeon, and Tripaphylus than it does the ovoid condition coded for Lophoura, Paeonocanthus, Periplexis, and Sphyrion. Dojiri and Deets (1988) also considered the trunk of Paeon spp. as gradually expanding, but the trunk of three of eight Paeon spp. (P. australis, P. triakis, and P. veriscolor) are not (Wilson 1919, Kabata 1993, Castro Romero 2001). And, Dojiri and Deets (1988) considered the trunk of Paeonocanthus antarcticensis (Hewitt, 1965) to be ovoid, but illustrations in Hewitt (1965), Kabata (1965), Hogans (1986b), and Ho et al. (2003) together denote trunk variation that challenges confidence in allocating a state of either ovoid or gradually expanding for Paeonocanthus.

Characters R and S (cephalothorax): we felt unsure operationally regarding the definitions used by Dojiri and Deets (1988) regarding these characters, especially in light of how little is known regarding the homology of various components of the sphyriid cephalothorax. For example, the cephalothorax of some Lophoura spp. (e.g., see Ho and Kim 1989, Boxshall 2000) appears bulbous to us, while other congeners seem to possess cephalothoracic protuberances (e.g., see Hogans and Dadswell 1985).

Character V (gut diverticulae): Dojiri and Deets (1988) considered Sphyrion and Lophoura spp. to possess a synapomorphy in the form of anastomosing gut diverticulae (see Najarian 1952). Kabata (1979) mentioned this feature in one sentence of general discussion as being unique to Sphyrion and Lophoura and Wilson (1919) mentioned the aforementioned taxa as sharing this characteristic while Paeon did not. However, the literature contains no information regarding the form of gut diverticulae amongst representatives of Driocephalus, Norkus, Opimia, Paeonocanthus, Periplexis, or Tripaphylus or the outgroup Ommatokoita.

Character W (first antenna): Dojiri and Deets (1988) considered the form of the adult female first antenna to be known for members of Opimia and Paeon. However, the 
only mention of this structure in Opimia (see Wilson 1908) is confusing and does not allow character state designation. Regarding Paeon, we are unaware of literature detailing the structure of the adult female first antenna of its species.

Character X (second antenna): Dojiri and Deets (1988) considered the form of the adult female second antenna to be biramous for Paeon spp. However, the literature contains no details regarding the condition of this appendage for $50 \%$ of Paeon spp., i.e., P. asymboli, P. australis, P. triakis, and $P$. versicolor.

No cladogram resulting from our analysis was unambiguously congruent with the cladogram for sphyriid genera presented by Dojiri and Deets (1988) even in light of taxonomic progress since 1988 (cf. Fig. 2A, B with C). Our consideration of Paeon as being comprised of 2 groups (see Tables 1,2) was supported by the fact that all of our trees depicted Paeon group A and Paeon group B as being independent from one another (Fig. 2A). In our analysis, monotypic Driocephalus (whose representative is only known from elasmobranchs) was placed as the sister taxon to Lophoura (all of whose representatives infect teleosts) on $50 \%$ of all shortest trees and as a sister taxon to a clade comprised of Lophoura and Sphyrion (both only known to infect teleosts) on the remaining $50 \%$ of shortest trees. None of our cladograms depicted Sphyriidae as being comprised of 2 clades (as did the results of Dojiri and Deets 1988), one consisting of taxa that infect only elasmobranchs (i.e., representatives of Norkus, Opimia, Tripaphylus, Paeon, and Driocephalus) and the other consisting of taxa that infect only teleosts (i.e., representatives of Periplexis, Paeonocanthus, Lophoura, and Sphyrion).

In all, our results do not convincingly support any of the host summary or ecological summary cladograms presented by Dojiri and Deets (1988), albeit one could surmise how additional parsimony informative characters might alter our results to support some or even all of the results of Dojiri and Deets (1988) (cf. Fig. 2A, B with C). Nevertheless, with our cladograms being supported by so few synapomorphies, we do not consider any of them robust enough to in turn support a consideration of host associations or ecological associations amongst sphyriids. And, based on the highly modified and morphologically simple habitus of sphyriid adult females and the difficulty in recognizing homology regarding their character states, as well as the lack of information regarding the morphology of sphyriid adult males and the relatively modified and simple morphology of known sphyriid adult males as compared to the adult males of many other siphonostome taxa (e.g., Kroyeriidae, Eudactylinidae, Caligidae, and others; see Kabata 1979, Benz 1993, Deets 1994), we believe that a robust phylogeny for members of Sphyriidae is best sought using molecular tools. Until such a phylogeny is realized, it seems premature to conduct analyses regarding the historical ecology (e.g., host associations, habitat associations, environment associations, biogeographic associations, etc.) of sphyriids.

\section{ACKNOWLEDGEMENTS}

We thank Norio Koyama (Shiba Branch of Yokohama City Fisheries Cooperative Association) for assisting with shark collections, Jeremy Wetmore (Southern Adventist University) for making preliminary observations of study specimens, Ash Bullard (Gulf Coast Research Laboratory) for assistance with electronic figures, and Dr. Zbigniew Kabata (retired, Pacific Biological Station, Canada) for raising our awareness of $D$. cerebrinoxius prior to the collection of the study specimens.

\section{REFERENCES}

Benz G.W. 1993. Evolutionary history of Siphonostomatoida (Copepoda) parasitic on vertebrates. Ph.D. Dissertation. The University of British Columbia, Vancouver, British Columbia, Canada.

Benz G.W., Lucas Z., Lowry L.F. 1998. New host and ocean records for the copepod Ommatokoita elongata (Siphonostomatoida: Lernaeopodidae), a parasite of the eyes of sleeper sharks. Journal of Parasitology 84: 1271-1274.

Benz G.W., Mollet H.F., Ebert D.A., Davis C.R., Van Sommeran S.R. 2003. Five species of parasitic copepods (Siphonostomatoida: Pandaridae) from the body surface of a white shark captured in Morro Bay, California. Pacific Science 57: 39-43.

Boxshall G.A. 2000. Parasitic copepods (Copepoda: Siphonostomatoida) from deep-sea and mid-water fishes. Systematic Parasitology 47: 173-181.

Boxshall G.A. 2004. An introduction to copepod diversity. Part II. The Ray Society Series 166. With Halsey S.H. The Ray Society, London.

Castro Romero R. 2001. Paeon triakis sp. n. and a new form for Lateracanthus quadripedis Kabata et Gusev, 1966 (Copepoda, Siphonostomatoida), parasitic on Chilean fishes in the South Pacific. Acta Parasitologica 46: 24-29.

Compagno L.J.V. 1999. Checklist of living elasmobranchs. Pp. 471-498. In: Hamlett, W.C. (ed.) Sharks, skates, and rays. The Johns Hopkins University Press, Baltimore.

Compagno L.J.V., Dando L.M., Fowler S. 2005. Sharks of the world. Princeton University Press, Princeton.

Deets G.B. 1994. Copepod-chondrichthyan coevolution: a cladistic consideration. Ph.D. Dissertation. The University of British Columbia, Vancouver, British Columbia, Canada.

Delamare-Deboutteville C., Nuñes-Ruivo L.P. 1954. Parasites de poisons de mer ouest-africains récoltés par M.J. Cadenat. II. Copepodes $\left(1^{\text {re }}\right.$ note) genres Lernanthropus, $\mathrm{Sa}$ gum, Paeon, Pennella. Bulletin de l'Institut Française d'Afrique Noire 16: 139-166.

Diebakate C., Raibaut A., Kabata Z. 1997. Thamnocephalus cerebrinoxius n.g., n.sp. (Copepoda: Sphyriidae), a parasite in the nasal capsules of Leptocharias smithii (Müller \& Henle, 1839) (Pisces: Leptochariidae) off the coast of Senegal. Systematic Parasitology 38: 231-235.

Dojiri M., Deets G.B. 1988. Norkus cladocephalus, new genus, new species (Siphonostomatoida: Sphyriidae), a copepod parasitic on an elasmobranch from southern California waters, with a phylogenetic analysis of the Sphyriidae. Journal of Crustacean Biology 8: 679-687. 
Hewitt G.C. 1964. A new species of Lophoura* (Sphyriidae, Copepoda) from New Zealand waters. Transactions of the Royal Society of New Zealand 5: 55-58.

Hewitt G.C. 1965. A new species of Periplexis (Sphyriidae, Copepoda) from the Southern Ocean. Transactions of the Royal Society of New Zealand 6: 103-106.

Ho J-s. 1975. Parasitic Crustacea. Pp. 69-72. In: Lane E.D., Hill C.W. (eds.) The marine resources of Anaheim Bay. California Department of Fish and Game Bulletin 165.

Ho J-s. 1992. Does Sphyrion lumpi (Kryøer) (Copepoda, Sphyriidae) occur in the Sea of Japan? With discussion on the origin and dispersal of Sphyrion Cuvier, 1830. Report of the Sado Marine Biological Station (Niigata University) 22: 37-48.

Ho J-s., Kim I-H. 1989. Lophoura (Copepoda: Sphyriidae) parasitic on the rattails (Pisces: Macrouridae) in the Pacific, with note on Sphyrion lumpi from the Sea of Japan. Publication of the Seto Marine Biological Laboratory 34: 37-54.

Ho J-s., Kim I-H., Nagasawa K., Saruwatari T., 2003. Paeonocanthus antarcticensis (Hewitt, 1965): a rare copepod parasite of bathypelagic fish, Bathylagus antarcticus Günther, from the Antarctic Ocean. Zoological Science 20: 1315-1321.

Hogans W.E. 1986a. The appendages of Lophoura tetraphylla Ho, 1985 (Copepoda: Sphyriidae) a parasite of Antimora rostrata in deep waters of the northwest Atlantic Ocean. Proceedings of the Nova Scotia Institute of Science 36: 127 130.

Hogans W.E. 1986b. Paeonocanthus antarcticensis (Copepoda: Sphyriidae) parasitic on the bathypelagic fish Bathylagus euryops in the northwest Atlantic Ocean. Sarsia 71:305307.

Hogans W.E., Dadswell M.J. 1985. Redescription of Lophoura gracilis (Wilson, 1919) (Copepoda: Sphyriidae) from Synaphobranchus kaupi in the Northwest Atlantic Ocean. Canadian Journal of Zoology 63: 2940-2943.

Kabata Z. 1965. Parasitic Copepoda of fishes. Report of the B.A.N.Z. Antarctic Research Expedition 6: 1-16.

Kabata Z. 1979. Parasitic Copepoda of British fishes. The Ray Society Series 152. The Ray Society, London.

Kabata Z. 1993. Two new species of Copepoda (Crustacea) parasitic on marine fishes. Systematic Parasitology 26: 233-239.

Kirtisinghe P. 1964. A review of the parasitic copepods of fish recorded from Ceylon with descriptions of additional forms. Bulletin of the Fisheries Research Station, Ceylon 17: 45-132.
Lewis A.G. 1966. Copepod crustaceans parasitic on elasmobranch fishes of the Hawaiian Islands. Proceedings of the United States National Museum 118: 57-154.

Moran J.D.W., Piasecki W. 1994. External morphology of the male and female of Sphyrion lumpi (Krøyer, 1845) (Copepoda; Siphonostomatoida; Sphyriidae). Hydrobiologia 292/293: 171-178.

Najarian H.H. 1952. The internal anatomy of Sphyrion lumpi (Krøyer, 1845) Bassett-Smith 1899, a copepod parasite on ocean perch. Journal of Morphology 91: 447-467.

Paterson A.M., Poulin R. 1999. Have chondracanthid copepods co-speciated with their teleost hosts? Systematic Parasitology 44: 79-85.

Raibaut A. 1999. Change of name. Systematic Parasitology 42: 75.

Roberts L.S., Janovy Jr. J.J. 2000. Foundations of parasitology, sixth edition. McGraw-Hill Companies, Inc., Boston.

Swofford D.L. 2002. PAUP*: Phylogenetic analysis using parsimony (*and other methods), version 4. Sinauer Associates, Sunderland.

Turner T.B., Kyne P.M., Bennett M.B. 2003. Description of Paeon asymboli n. sp. (Copepoda: Sphyriidae), parasitic on Asymbolus spp. (catsharks) and a new host record for P. australis Kabata, 1993. Systematic Parasitology 56: 235-239.

Wilson C.B. 1908. North American parasitic copepods: a list of those found upon the fishes of the Pacific Coast, with descriptions of new genera and new species. Proceedings of the United States National Museum 35: 431-481.

Wilson C.B. 1919. North American parasitic copepods belonging to the new family Sphyriidae. Proceedings of the United States National Museum 55: 549-604.

Wilson C.B. 1932. The copepods of the Woods Hole region, Massachusetts. Bulletin of the United States National Museum 158: 1-635.

Yamaguchi A., Yokoyama H., Ogawa K., Taniuchi T. 2003. Use of parasites as biological tags for separating stocks of the starspotted dogfish Mustelus manazo in Japan and Taiwan. Fisheries Science 69: 337-342.
Received: 5 April 2006 Accepted: 6 June 2006 